\title{
Building a Civilization Base on Spiritual Values: Learning from the Struggle of Husain
}

\author{
${ }^{1}$ Fadhlu Rahman, ${ }^{2}$ Anas Amarulloh, ${ }^{3}$ Fitri Siska Supriatna \\ STFI Sadra, Universitas Negeri Yogyakarta (UNY) , STFI Sadra \\ 1anasamarulloh@gmail.com \\ 23Gt630111@gmail.com \\ ${ }^{3}$ Fitrisiskasupriatna21@gmail.com
}

\begin{abstract}
The modern paradigm gives a strong influence to the modern people especially in the west. The influence is from its coup to the reality of God by some western thinkers and intellectuals. Than it has the impact to the meaning of advance civilization, futher it gives serious problems to the most social structure. The struggle of Sayyidana Husain as the everlasting history of humanity gives another view to the human concept and advance civilization. The oneness values (tauhid) which is contained by al-Husain, look at the spiritual aspects as the measure of the advance civilization. Therfore the definition of advance civilization has a new space, and opens the way of the inherent potentials as the basic of the advance civilization. This writing tries to open the values of Sayyidina Husain's struggle in Karbala and mixs it contextually with the concept of Coomaranswammy's spiritual civilization as the basic meaning of civilization by using the historical and analysis descriptive method. Hence the paradigm of advance civilization has an alternative of the new paradigm, and the spirituality can be a measure of advance civilization.
\end{abstract}

Keywords: Spiritual civilization, oneness, Husain

\section{Introduction}

Everything in the world is inseparable from the particular paradigm that directs it. According to Thomas Khun, the term Paradigm Shift quoted by Fritjof Capra states that a scientific truth is nothing but based on a collection of concepts, values, and perceptions of a particular society from which a visible perspective or vision of world reality ${ }^{1}$. According to Khun that the objectivity of truth depends on those collections of values. This means that the majority of the group becomes the determinant of the vision of a truth. The western vision constructed by the Renaissance

${ }^{1}$ Fritjof Capra, The Web of Life, (New York: An Anchor Book, 1996), p. 6

AJIS : Academic Journal of Islamic Studies vol. 4, no. 2, 2019

IAIN Curup - Bengkulu | p-ISSN 2580-3174, e-ISSN 2580-3190

Available online: http://journal.staincurup.ac.id/index.php/AJIS 
and Enlightenment has had a very significant impact on civilization, and its outlook on the world provides materialistic direction to western society $^{2}$. This vision is born from philosophers and scientists who have a strong community of rationality. Descartes, Hobbes, and Bacon became the pioneers of the birth of the modernist paradigm. They termed this era as Turning to nature directly, turning to mind directly and turning to experience directly3. From here came the term Nasr called "removing God from the center of the reality and putting man in His place".

God's authority was substituted by humans. They regard it as a concept that lies in man, not an independently existing reality. One of them is clearly justified by Mario Bunge's theory of mind identity. He is one of the western modern philosophers and physicists who show that every thought is a function of the brain's nerves, meaning if the brain does not exist then the mind does not exist ${ }^{5}$. Likewise God as a thing conceived by man can be lost with the missing or damaged the human brain. God's setting by most of these western thinkers gave rise to the concepts of the progress of materialistic civilization. Maxwell J. Mehlman and Jhon Harris for example, two materialists who define human quality improvement as an improvement in physical performance, appearance and capability 6 . Thus, the human being who is an icon of civilization is said to be advanced when it develops or increases its physical aspects. In other words, advanced civilization is the place for a group of people who whisper forward. This leads people to materialistic self-development.

The worldview of civilization adopted by the West for centuries has given birth to a crisis in various aspects, not just science, but sociocultural. This is in line with Capra's words that see the obstacles of modern physics objectivity as the cause of the various crises and make modern physics as a paradigm for viewing the universe "Accordingly, what we are seeing is a shift of paradigm not only within science, but also in

\footnotetext{
2 Toby E Huff,.The Rise of Early Modern Science, (New York: Cambridge University Press, 2003), p. 327

${ }^{3}$ Donald M Borchert, Encyclopedia of Philosophy, (New York: Thompson Gale Corporation, 2006), p. 316

4Seyyed Hossein Nasr, In Search of the Sacred, (Colorado: Praeger, 2010), p. 209

${ }^{5}$ Mario Bunge, Matter and Mind, (Montreal: Springer, 2010), p .160

${ }^{6}$ Ronald Cole-Turner, Transhumanism and Transcendence, (Washington DC: George Town University Press, 2011), p. 1
} 
the larger social arena ". In addition, he adds that this provides an existential problem to mankind, "their problem was not merely intellectual but an extinct emotional, and one could say, even exsistential crisis"7. Thus the paradigm of Western civilization is precisely the birth of various problems in practice. This then leads to a vagueness of the definition of the progress of civilization, previously proposed by western materialists as an increase in physical or material aspects.

When the materialists practically experience the vagueness of the definition of the progress of a civilization, Islam comes to provide an alternative definition of progress, with the events of Karbala Sayyidina Hussein. This event has historically occurred when the Islamic government was held by Yazid Ibn Muawiyah which was justified by some historians as an authoritarian and contrasting leader of Islamic values. From it the government without divine values is the basis of power ${ }^{8}$. The Muslim community then experienced a spiritual turmoil and thirst for the values of justice. This led to Husein raising his heart to fight the injustices of the government. He rose as a leader of the mustadafin and revitalisator of the teachings of his grandfather Rasulullah, who advanced high civilization'. The process of al-Husein's grandson of the Prophet created various high values and indirectly provided an alternative meaning to the progress of a civilization.

After all, the civilizations referred to by this event can not escape the claims of the meaning of modern civilization, related to the different human concepts proposed by both. So that Ananda Coomaraswamy is a perennialist philosopher became a foothold for defining civilization in the context of spiritualism. His article entitled What Is Civilization? briefly discusses the concept of spiritual civilization. He uses a literal approach in defining civilizations that allow the values of the struggle of Sayyidina Husein to be said as civilization. Thus the values of the struggle of Sayyidina Hussein have a place to define the progress of a civilization. In the context of this issue, the author seeks to elaborate further on the event by using the historical analysis approach as well as

${ }^{7}$ Fritjof Capra, 1996,p. 6

${ }^{8}$ Heriyanto, Husain, Hikmah Abadi Revolusi Imam Husain, (Jakarta: Sadra Press, 1435), p. 346

9Jalaluddin Rakhmat,. Islam Aktual, (Bandung: Mizan, 1991), p. 293-294 
Coomaraswamy's theory of civilization. This is so that the progress of civilization to get an alternative definition through the values of the struggle of Sayyidina Hussein, as well as prove that spirituality can be used as a measure of the meaning of the progress of civilization. From this hypothesis the author tries to justify by explaining the concept of Spiritual civilization, Values of Spirituality, and the values of the struggle of Sayyidina Hussein and the model of the progress of spiritual.

\section{The Concept of Spiritual Civilization}

One who can define civilization in this context is Ananda Coomaraswamy, a philosopher perennialist. In his article entitled What is Civilization?, he sought to explain the intrinsic meaning of the terms "civilization", "politics" and "purusa". These three things become the basic principle of the meaning of civilization will be discussed. This he addressed in response to Abert Schwitzer's question, which sees the obscure meaning of modern western civilization. Coomaraswamy begins by defining the civilizations of Greek and Sanskrit. In Greek it is rooted from the word keisthai, Sanskrit si, meaning to lean, or take place. So this language is defined as the place where the citizens live, or he termed "in which the citizen makes his bed"10.

Then who lives? or who is the resident? He states that the purusa is the one who lives in it. Purusa is a unity of two words of political meaning rooted in pla and pimplemi. These two words mean "serve", and "fortress".11 This means that there are two elements of language in the place, among others, servants and guards as a fortress. So that if we contextualize these two things in one place, then means the existence of citizens and kings.

The citizen he means as a man whose king is God. Coomaraswamy quotes Plato's conversation with Philo in The Republic. Philo says that God is the king of the place: "As for lordship (Kyrios), God is the only citizen" while the man whom he attributes to Adam is his citizen: "Adam

${ }^{10}$ Ananda K Coomaraswamy, What is Civilization?, (United Kingdom: Lindisfarne Press, 1989), p. 1

${ }^{11}$ Ananda K Coomaraswamy, The Essential Ananda K. Coomaraswamy, (Bloomington: World Wisdom, 2004), p. 201 
is the only citizen of the world"12. Both of these become elements of the place in question, and both must be mutually sustainable in order to create a harmony in a government.

Then where is the city located? Coomaraswamy mentions that it is overwhelmed by the human self. In the human heart is the city of God as an absolute reality housed. From it all the energies of human potential are sourced: "Thus at the heart of the City of God inhabits the omniscienct, immortal Self," the self-immortal Self and Duke, "as the Lord of all, the protector of all, the Ruler of all beings and the Inward Controller of all the powers of the soul"13. Undoubtedly incomprehensible to the place of God means that his or her existence or existence exists in man, but God's city can be found in man as Plato says: "as of the city is within you and literally at the of the city"14.

The city of God serves as the source of all energy for human potential. Soul and body without it is weak and helpless. Its presence in man is like a king who always keeps the existence of man. Coomaraswamy analogizes it like someone who always gives offerings to the Altar, where he always hopes to stay by asking for the protection and welfare of his life. This relationship is able to give hope to humans to always exist and get a comfortable place as a citizen. Thus a good citizen is the most obedient to his king ${ }^{15}$. So God is made the center to do all human activity, because God, a servant moves to do what he commanded. Thus the relationship between God and man is very intimate, and it becomes a necessity for man to obey God completely so that his life in the city of self can work well.

In a government there must be a law running. This is called Coomaraswamy as a form of a nature ${ }^{16}$. it refers to all the potentialities of the human soul, which all of these will bring man to his heart as the source of his energies. Justice becomes a matter of being upheld by a good government, as well as the potentials of the soul. if all the potential of the soul is actual in accordance with the nature of potential as a form of

\footnotetext{
12Ananda K Coomaraswamy, 2004, p. 202

${ }^{13}$ Ananda K Coomaraswamy, 2004, p. 202

${ }^{14}$ Ananda K Coomaraswamy, 2004, p. 202

${ }^{15}$ Ananda K Coomaraswamy, 1989, p. 5

16 Ananda K Coomaraswamy, 2004, p. 201
} 
justice, there will be a harmony or justice. This harmony then leads one to the center of all its potential energy regulators, as he says: "The right and natural life of the powers of the soul is, precisely, their function of bringing the tribute to their fountain-head, the controlling Mind and very Self17.

This situation necessarily requires a good self-knowledge, and know the characteristics of these potentials, so that he can use them in accordance with the nature. Al-Kashani, an Islamic philosopher described by K. Vasiltov, said that "self-knowledge is capable of attaining an inner awareness of the absolute reality (God) ${ }^{18}$.

To be able to achieve this then At least there are some elements of the characteristics required to create a self-governing order of justice. According to Coomaraswamy it includes: wisdom (wisdom), peace of mind (sobriety) and courage (courage). All God-given potentials such as hearing and sight should be used proportionately, because It is a requirement of the attainment of these characteristics, that man is said to be human when all his potential can function properly. This thus leads to an absolute reality. On the contrary if man can not use his potential proportionally, then he will be far from absolute reality ${ }^{19}$. From the concept he built it can be concluded that the civilization in question is a place that is within a person. Civilization in the form of no other city is occupied by God as its king and man as his society. The justice that is done within a person becomes a condition for the achievement of perfection of government within. It is obtained by all its potentials that are used proportionately, so that the principles needed to be created this state is meeting the material and nonmaterial needs that exist within a person. This is so a good civilization in this context is how far a person is able to meet his or her needs. This Coomaraswamy quotes from the book Republic: "this purpose is to satisfy a human need" 20.

\section{Spiritual Values}

\footnotetext{
${ }^{17}$ Ananda K Coomaraswamy, 2004, p. 205

18Vasiltov K. Afdal al-Din Kashani and His Treaties: The Book of Everlasting,Vol. 10, No 4 Orientalia, 2004, p. 10

${ }^{19}$ Ananda K Coomaraswamy, 2004, p. 205

${ }^{20}$ Ananda K Coomaraswamy, 1989, p. 205
} 
Spirituality is a second prerequisite to be able to explain the value of the struggle of Sayyidina Husain, as well as a gateway to the context of the progress of civilization by Sayyidina Husain. In Latin the spirituality comes from the word spirit which means spirit, soul, soul, unborn form, breath, or life. The spiritual means spiritual, spiritual, and moral. While spirituality is a process to achieve the highest peak awareness. Of these three syllables we can delineate the meaning of spirituality as a process to achieve self-actualization based or driven by spiritual power ${ }^{21}$. This means that the core of self-actualization power comes from a spiritual substance. This spiritual substance is confirmed by Nasr in his book In Search of the Sacred: "is the spirituality is to be in contact with the world and the transcends all the particularities of the human state and of the materal world"22.

This spiritual thing becomes a distinct dimension in man. Spirit is a core reality of man. From it all the power of human potential comes from. This if associated with the concept of Coomaraswamy city, then the status is the city of God. previously mentioned as the center of all human existence. Irham Iqbal in his dissertation puts the position of the Spirit as the genus of the soul. its relality is directly related to Divine aspects. Without it soul can not function, so the soul can not move the material potencies such as sight, hearing, smell, touch and taste ${ }^{23}$.

The existence of the spirit is deeply blessed with the soul. The soul of human nature is positioned between two ontological realities, namely, the spiritual in the form of the spirit, and the material being. The human soul moves towards a certain direction its movement depends on the use of its potentials. many philosophers have alluded to the concept of the process of the movement of the potentialities of the soul. Among the most famous are al-Ghazali and Ibn Miskawayh in his book Kimiya al-Sa'adah and Tahzib al-Akhlak, quoted by Nur Hanim. Both in detail describe the soul potentials of three core faculties, among others: al-quwwah alnatiqah, al-quwwah al-ghadabiyah, and al-quwwah al-shahwiyah. While al-Ghazali mengistilahkannya with the term nafs al-insaniyyah, nafs al-

${ }^{21}$ Muhammad Irham Iqbal, Menghidupkan Spiritualitas Islam: Kajian Terhadap Konsep Hudur Ibn al-Arabi, (Jakarta: Semesta, 2016), p. 37

22Seyyed Hossein Nasr, 2010, p. 168

23Muhammad Irham Iqbal, 2016, p. 30-32 
hayawaniyyat and nafs al-hayawaniyyah. Each of these three potentials have two positions, among others, the advantages and kekekarangan altafrit and al-ifrat. Al-Ghazali and Ibn Miskawayh used the doctrine of the middle way as the main position of al-wasat. So that the soul that successfully uses its potential is the soul that gets the middle position of each of its potentials such as: al-hikmah, al-just'ah, and al-iffah ${ }^{24}$. The third state of this soul that can lead man to the center of his soul in the form of spirit and get the highest awareness of the universe.

The highest consciousness becomes the culmination of the true human condition. With it one can see the reality of the world as it is. This ability is based on the human nature that is part of God. This is justified by the cosmic creation process that Muslim philosophers call emanation, ${ }^{25}$. or the Suhrawardi theory that specifically states that man is a part of God's light graded from the immaterial globe to the material peak, ${ }^{26}$ so does Mulla Sadra which mentions that man comes from one essential reality. He became the source of another explanation of reality ${ }^{27}$. These theories indicate the status of human beings who have the characteristics of God because they are created from the Divine part (attributes). so that human beings are enabled by God to gain ultimate consciousness.

Associated with the process of obtaining the highest awareness knowledge, Nasr in his book Knowledge and The Sacred states: "The answer of the tradition is that of the nature and the nature of the nature and the nature of the nature and the nature of the nature and the nature of which is tasted and experienced, the cowence which the Islamic tradition refers to as "presential knowledge"28.

${ }^{24}$ Nur Hanim, Pendidikan Akhlak: Komparasi Konsep Pendidikan Ibnu Miskawaih dan al-Ghazali, vol. 18, no 1, Ulumuna, 2014, p. 27

${ }^{25}$ Seyyed Hossein Nasr, The History of Islamic Philosophy, (London and New York: Routledge. 1996), p. 446

${ }^{26}$ Peter. S Groff, \& Oliver,Leaman, Islamic Philosophy A-Z, Edinburg: Edinburg University Press, 2007), p. 20

${ }^{27} \mathrm{Sadr}$ al-Muta'alihin Shirazi, Mazahir al-Ilahiyyah fi asrar al-Ulum al-Kamaliyyah, Tehran: Sadra Foundation of Islamic Philosophy. 1999), p. 15

${ }^{28}$ Seyyed Hossein Nasr, Knowledge and the Sacred, New York: State University of New York Press, 1989), p.119 
That the consciousness of absolute reality can be obtained through two epistemology namely, revelation and intellectual intuition. The process of acquiring such knowledge by presenting it within. This knowledge is often referred to by some Muslim philosophers as hudhuri science which means to present itself. What distinguishes between hudhuri and hushuli is the intermediary that it uses. Hudhuri does not use mental intermediaries at all to gain a science while hushuli use mental intermediaries ${ }^{29}$. Ibn Turkah is quoted by Khomeidi to call this the angelic incoming thought, in which man specifically gets it after the purification process ${ }^{30}$. meant not arbitrarily without the process of reasoning theoretical reason. Ibn Turkah says that the good we do must be based on a theoretical sense decision. That is, however, the role of the theoretical reason must be balanced with the process of self-purification that is prepared to receive God's knowledge ${ }^{31}$. Further in practice, Fariseh Tayefeh's dissertation of Abdurrazaq al-Kashani with his book Tuhfah al-Ikhwan Fi Khasais al-Fityan states that the knowledge of absolute reality can be obtained through the properties of praise. These qualities he quotes from Sayyidina Ali include: loyalty, security, humility, generosity, repentance, counsel, protection and honesty ${ }^{32}$. With these praiseworthy attitudes man will gain a true awareness of his existence and gain an essential knowledge of the reality of the divine. This consciousness as al-Ghazali and Ibn Miskawayh alluded to as a balanced use of the potentialities of the human soul, or Coomaraswamy referred to as a true servitude to God in the human heart. All this is none other than the spirit spirit of man who always leads to God.

\section{The Sacrifice of Sayyidina Husayn and the Progress of Spiritual Civilization}

${ }^{29}$ Muhsin, Labib, Pemikiran Filsafat Ayatullah M.T. Misbah Yazdi, Jakarta: Sadra Press, 2011), p. 158

${ }^{30}$ Faridi, Mona Khorsidi,. Comparing Mulla Sadra and Ibn Turka Viewpoints Regarding Angelic Inspiration, no 2, vol. 3, Basic. Appl. Sci. Res 2013), p. 582

31Faridi, Mona Khorsidi, 2013, 582

${ }^{32}$ Hastrodi, Fatimeh Tayafeeh Aghakhan, Concept of Chivalry (Futuwwah) According to Abd al-Razzaq Kashani: Analysis on His Tuhfah al-Ikhwan fi Khasais al-Fityan. PhD, Faculty of Islamic Thought University of Kuala Lumpur, Kuala Lumpur, 2015), p. 144 
The struggle of Sayyidina Husayn, has historically left behind certain values that can be learned. The wisdom it contains becomes the fruit of interpretation for certain groups or groups. But there is a universal value standard given by the story. The value is none other than humanity. All human beings who understand its history can not deny the necessity of the history of Sayyidina Husain as a form of awareness of the human heart ${ }^{33}$. The meaning given by his story is always remembered and gives much mystery to the values of humanity. These values are then the center of excavation of science and encouragement of the struggle of various nations to move forward develop its civilization, even al-Husain is seen by every society in the world as "International Heroes" who uphold the truth regardless of race, group, nationality, heredity and so on, as Ahmed Ali says: "People in every part of the world, without any distinction of caste, creed, color or nationality, love Husain and hold him in reverence, recognizing and hailing him as a Great Hero of Truth" 34 . This is none other than the quality of sacrifice. According to Husain Shahab to measure the parameters of one's sacrifice, we can judge from three things. First the purpose of the sacrifice itself, the second what is used as a sacrifice, the three who sacrifice ${ }^{35}$.

The purpose or purpose of sacrifice determines a quality sacrifice. From him someone knows the achievement of what he sacrificed. Of course different, people who sacrifice to uphold universal truth with people who sacrifice to just family prosperity. Like Socrates, for example, a man willing to sacrifice his life, so that the wisdom of that time will survive compared to the sacrifice of a husband who feeds his family in order to achieve the welfare of his family. It's the same with what quality a person sacrifices. The sacrifice of money is no more than life. So also about who sacrifices, this is very menementutukan quality sacrifice given. Simply put, our mind will judge if ordinary people who sacrifice themselves to die compared to clerics or presidents, then ulama or president is more meaningful, given their preparation in a very important social status.

${ }^{33}$ Husain, Heriyanto, 1435 H, 160

${ }^{34} \mathrm{Ahmed}$, Ali, S.V. Mir, Husain: The Savior of Islam, Qum: Ansarian Publication, 2005), 213

35Husain, Heriyanto, 1435 H, 181-182 
Thus the preparedness, purpose, and what was sacrificed by the struggle of Sayyidina Husain became a parameter to assess its sacrifice. With that, we know the values given the history of sacrifice. This knowledge which, then we compare with the concept of civilization and spirituality. This is so that we can know the relation between these values with the concept of a Coomaraswamy civilization and the spirituality proposed by the urafas as well as knowing how those values are applied in the context of spiritual civilization.

\section{Get to know Sayyidina Husain}

Sayyidina Husayn's abilities are nothing more than the history of his life. Starting from a small he was raised by the noblest people in the world. His grandfather Rasulullah became a direct educator of Sayyidina Husain, so that his days always passed with the Messenger of Allah. Husain's name is a direct command of God. The Messenger of Allaah quoted by Sayyid Abbas Salehi from the book of Mu'jam al-Kabir said: "Aaron (brother of Moses) gave his sons name" Syabbar and Subbair, I named my grandchildren with Hasan and Husain ${ }^{36}$.

After the naming of these days al-Husain is always filled with the love of the Prophet as his way of education. The love of the Messenger of Allah revealed to his behavior and his words about al-Husayn. Not infrequently he displays his love in public. He picked up and kissed al-Husain so that his friends often wondered and said, "I have a son, but I never kissed him at all." He (the Messenger of Allah) said: "Suppose God SWT, pluck out a sense of affection from your heart, what is my sin?" 37 . On another occasion, when one friend saw him kissing Husain, he said, "I have ten children none of whom I kiss." The apostle replied, "The person who does not give love, then he will not get the grace of Allah $S W T^{\prime \prime 38}$. The expression of the Messenger of Allah on the level of al-Husain in the eyes of the inhabitants of the universe, he always expresses in his words. The most popular sayings of the Prophet one of them is, "Husayn is part of me and I am a part of it [Husayn minni wa ana minhu" Sayyid Abbas Salehi analyzed the

\footnotetext{
${ }^{36}$ Husain, Heriyanto, $1435 \mathrm{H}$, xxvii

${ }^{37} \mathrm{Abu}$ Abdillah, Ahmad bin Muhammad, Ibn Hanbal. Fadha'il al-Shahabah, Vol. 2. Beirut: Muassasah al-Risalah, 1403 H), p. 769

38Husain, Heriyanto, $1435 \mathrm{H}, \mathrm{xx}$
} 
statement of the Prophet. He came to the conclusion that what the Apostle said about Husayn was not just a genetic relationship. It is true that we conclude that "Husayn is part of $m e$ " is a genetic statement, but this is not true in Saleh's statement "I am part of it". This means that a grandson may not be a genetic standard to his grandfather, since the genetic relationship must be one-way from the old to the young, from the Apostle to Husain not the other way around. This is so Salehi sees the relationship between the two is a relationship beyond the reach of the physical (metaphysical) ${ }^{39}$. In his Ummah the Prophet once told a causal relationship of love, between himself and Husayn. The Apostle said, "Who loves this man [Husain], then he has loved me [man ahabba hadza faqad ahabbani]" or the statement, "Who loves me, then love these two men [Man ahabbani, falyuhibbu hadzayn]". So close is the love that was built by the Prophet to al-Husayn, so we know that the love he built is not limited to the level of materiality ${ }^{40}$.

The figure of Sayyidina Husayn we know through the words of this Prophet became the reason of the predication against Sayyidina Husain as a spiritually perfect man. The proof of this claim is found in the hadith of the Prophet narrated by Abu Hasan quoted by Husayn Sahab, when the Messenger of Allah replied to Ubai's question that there was no one other than the Apostle who could be the decorator of heaven and earth (zany al-samawati wa al-aradhi ). Apostle's Answer: Hi Ubai, by the One who sent me correctly as the Prophet, Husayn ibn Ali is more supreme in the heavens than on earth. It is written on the right hand of the Throne of God a sentence:

"Husayn is the lamp of hidayah, the ark of salvation, the leader of goodness, glory, pride, knowledge and wealth. Really Allah 'Azza wa Jalla has placed in its sulbinya a good seed, a blessing and a holy; and has taught him the prayers that this creature might have sinned with him then he will be with him, and will have his intercession in the hereafter; and his sorrow will also be lifted, his debt shall be dealt with, his way will be illuminated, his enemy will be defeated and his disgrace will be covered " (Heriyanto, 1453: 184) ${ }^{41}$.

\footnotetext{
${ }^{39}$ Husain, Heriyanto, $1435 \mathrm{H}, \mathrm{xxv}$

40Husain, Heriyanto, $1435 \mathrm{H}, \mathrm{xxv}$

${ }^{41}$ Husain, Heriyanto, 1435 H, p. 184
} 
If associated with the concept of Coomaraswamy then al-Husain is seen as the owner city self is good. Because in him there are noble traits such as what the Prophet mentioned, so that a justice created fully in his civilization. All things that are predicted to al-Husayn reflect his own greatness on the nonmaterial level, and if associated with irfan then his spiritual Characteristic which has been mentioned by the Prophet signifies the status of the Spirit that is in direct contact with God. Without having to test the behavior of al-Husain, Muslims know that he potentially has reached the height of morality, because the personal characteristics of al-Husayn mentioned in the words of the Prophet, who every word is not in the slightest mistake, "Wa ma yanthiqu 'al-hawa in huwa illa wahyun yuha ", (He [Muhammad] does not say anything from his lusts, but all of them are revelations revealed to him) (QS, al-Najm: 03). With a glimpse of the description of this figure of Sayyidina Husayn, it can be concluded that al-Husain tested to assume the status of the owner of perfect self civilization, before then tested his behavior. His conduct will, in any case, reflect the virtues that his values can take as a form of civilization's progress. This is clearly reflected in al-Husayn's struggle in Karbala, which is the purpose of sacrifice and what he sacrifices.

\section{The Dedication and Sacrifice of Sayyidina Husain}

The purpose of sacrifice of Sayyidina Husain in humanity can be seen from the story of his struggle in the field of Karbala. Sayyidina Husain's words at the time of the war of Karbala illustrate the ultimate goal: "Surely I have not risen on the basis of ugliness and vanity, or corruption, and committing injustice, yet I rise up in order to improve the condition of my grandfather" 42 . These words indicate the main purpose of what is alHusain did at that time. He rose in response to the bad socio-cultural circumstances of Islam. Then what kind of bad circumstances meant by Sayyidina Husain? After the departure of Rasulullah, and then the power held full by Umayyah, Muslim society experienced a significant change. The changes from one era to the next can be interpreted two things: first the change occurs without any change in fundamental aspects or values, which in this context is the Qur'an and Sunnah of the prophet as the foundation of the law. The two changes that change all aspects or values

42Al-Muqarram, Maqtal al-Husayn, (Najaf: Adab. 1392), p. 156 
of previous times. The change made by this government according to Shakh Muhammad Mahdi Al-Asifi translated by Umar Kumo is in the second type. "The Muslims reverted to pre-Islam (Jahilliyah) customs and values although they did not renege on Islam. However, pre-Islamic customs, values and ideas returned and the umayyads regained, in the new dispensation, the position of influence which they occupied during the preIslamic period, base on the same values and concepts" 43 .

This condition is interpreted by al-Asifi as not functioning of human nature (innate nature) as its function. The government held by Muawiyyah's leadership belt followed by his son Yazid wiped out the tendency of human nature. Al-Asifi measured this from the disappearance of certain qualities previously existing and championed by the leadership of the Prophet: "To explain this point further, when human nature is unimpaired, qualities flow from it such as mercy, faith, sincerity, righteousness, affection, , decency, loyality, gratitude, chastity, self-esteem, truthfulness, trustworthiness, knowledge and justice ${ }^{44}$. These attributes serve as a benchmark to distinguish the leadership situation held by the Prophet with Muawiyyah and Yazid. Characteristics proposed by al-Asifi as a measure of leadership include faith, sincerity, righteousness, affection, piety, decency, loyalty, gratitude, chastity, self-esteem, truthfulness, trustworthiness, knowledge and justice are closely related to the characteristics built by uraphas and Coomaraswamy in see the quality of civilization and self-spirituality. In the view of the spiritualists These proposed circumstances are the driving force of the strong relationship between God and man in self-government.

On the basis of the loss of this situation al-Husain rose and wanted to reestablish the values of leadership championed by his grandfather, the Messenger of Allah. The process that al-Husain did in striving for it reflects the whole purpose. He is not based on the ways of love. Not a bit terbesit ways that invite lust and anger as said by Haidar Bagir: "Karbala not a matter of hatred. Carbala may involve great evil and wickedness throughout history, but still it is a matter of love" 45 . This statement is

${ }^{43}$ Syekh Muhammad Mahdi Al-Asifi, Ashura, (trans. Umar Kumo, Najaf: ABWA Publishing and Printing Center. 1425), p. 117

${ }^{44}$ Syekh Muhammad Mahdi Al-Asifi, 1425, p. 118

${ }^{45}$ Husain, Heriyanto, 1435 H, p. 352 
indirectly affirmed by Murtadha Motahhari in The Truth About AlHusayn's Revolt translated by Najim al-Khafaji: "His revolt was free from any angry reaction; rather, it was a purely Islamic uprising" 46 . This love which then opened the door of forgiveness for his enemies, until a Hur who had time to fight him repented and obedient to what brought alHusain. the openness and tolerance that Husayin spread at the time only affected a small part of his enemies. According to al-Asifi, the reason for this is the diminishing tendency of the divine nature which is the center of the human consciousness of the absolute reality. He concluded that the materialistic forces promoted by Yazid had obscured the Divine view of the Islamic community at that time ${ }^{47}$. In these circumstances al-Husain gave sparks of spiritual consciousness. Awareness given by al-Husayn reads: "do not you see that good is not done now?"48. These words signify a form of awareness for the people of that era. The meaning of goodness that al-Husain means when viewed from the context and his behavior is the awareness of human self-spirituality, which had previously been mentioned experiencing blurring, because the materialistic government Yazid. Kindness becomes the benchmark of a full awareness of an absolute knowledge as al-Kashani is quoted by William Chittick as saying: "The divine attributes and qualities that people must know about are virtues" which is a word full of Koranic resonance" 49 . With kindness according to al-Kashani can re-enable divine attributes (divine attributes).

The words of al-Husain in the form of the question had awakened one to recognize the inner aspects. This is so what al-Husain wants to fight for is the people who have a strong inner attachment with God, by applying the good as a way of obtaining Divine consciousness. In the purpose of the war none of al-Husain has the mind to rule. This manifests itself in the process of fighting. What he prepares for his followers in war is not physical preparedness, but the inner preparedness to face death. AlHusain's inner readiness can be identified from his words, and his speech

\footnotetext{
46Murtadha Muthahhari, The Truth about al-Husayn's Revolt, trans. Najim al-Khajifi, (London: MIL London. 2002), p. 6

47 Syekh Muhammad Mahdi Al-Asifi, 1425, p. 119

48Syekh Muhammad Mahdi Al-Asifi, 1425, p. 119

${ }^{49}$ William C, Chittick, The Heart of Islamic Philosophy: The Quest for Self-Knowledge in Teachings of Afdal al-Din Kashani, (New York: Oxford University Press. 2001), p. 73
} 
on the way to Iraq, publicly and personally to everyone. One of his speeches was quoted by al-Asifi from Ibn Tawus in his book Al-Luhuf which he translated into English:

"Praise be to God. Whatever God wills [is going to happen], there is no power except God. May God's blessings be on His Apostle. Death has been destined for the children of Adam the way a necklace is destined [to hang from] a girl's neck. My yearning for my forefather is like jacob's yearning for Joseph. A [form of] death has been chosen for me and I will meet it. It is Nawawis and Karbala. Then, surely, empty stomachs and starved bellies will be filled with remains. There is no escape from a day that has been inscribed with the pen [of destiny]. God's pleasure is our pleasure, we who are the Ahl al-Bayt. We shall persevere in his trial and he will give us in the rewards of the patient ones. The piece of flesh of God's Messenger (S) will never be separated from him; it will be gathered for him in paradise, and he will be delighted with him, what he has been promised will be fulfilled. Therefore, he who is prepared to lay down his life for his sake and has made up his mind to meet God should be set out in the morning, by will of God" (Asifi, $1425 \mathrm{H}: 32)^{50}$.

From what al-Husayn says very clearly signifies the preparation he made. He wants everyone to fight for the religion or the values that his grandfather strives for and to prepare for a happy death, because that is part of God's happiness. He teaches his people to know the true happiness that is behind death. This then awakened his people to prepare inwardly in battle. Not the slightest desire al-Husain indicated to rule. In fact he was convinced that the end of his physical life would take place in Karbala. That is logically, he with his transcendent knowledge knows that that power will not be possible. This indicates that what Husayin taught his followers is a full awareness of himself to return to the source of all the forces within him. God became the main principle of all his efforts. He taught them to surrender all effort to God. The teachings of al-Husain to his army of approximately 72 including his family managed to enter into the depths of their hearts. When Ali Akbar his son asked, "are not we in truth?" Sayyidina Husain replied, "of course we are in the truth". Responding to Husain's words the child replied, "then we are not afraid of

${ }^{50}$ Syekh Muhammad Mahdi Al-Asif, 1425, p. 32 
death!" With all his teachings he must accept the consequences of killing his family and friends. Seeing this situation al-Husain remains on ketauhidannya. As his prayer response when looking at this situation. "O my Lord, I am pleased with all Your pleasure, I am patient with all these disasters, and I submit to all Your commandments, none is worthy of worship but You." If this is seen from the perspective of Coomaraswamy civilization theory then al- Husain has succeeded in teaching his people to build an ideal civilization in his followers as well as him, because the relationship between God and Man (his people and himself) has merged into one consciousness or so-called Sufis as al-fana ${ }^{51}$. From this state the needs of human spirituality are fulfilled as aspired by the civilization principle of Coomaraswamy spirituality.

\section{Conclusion}

From the above explanation can be concluded that civilization in the spiritual context is interpreted as a civilization that exists within man. In it God becomes king, man becomes his people and nature becomes his law. It sees the quality of oneness as a form of attainment of fitrah which is the perfect law. Al-Husain as a humanitarian fighter raised the divine values as the basic principle of his struggle, which is the meaning of the progress of spiritual civilization of Coomaraswamy. This can be proved by the quality of his sacrifice in the form, purpose, personality, and what he sacrificed, as well as the way he did in the face of the Karbala tragedy. The way it fully shows absolute servitude to God which is the culmination of the ideal of spiritual civilization.

\section{Bibliography}

Ahmad bin Muhammad, Abu Abdillah, Ibn Hanbal, Fadha'il al-Shahabah, Vol. 2. Beirut: Muassasah al-Risalah. 1403

Ali, Ahmed, S.V. Mir,Husain: The Savior of Islam, Qum: Ansarian Publication. 2005 Al-Asifi, Syekh Muhammad Mahdi,.Ashura, trans. Umar Kumo, Najaf: ABWA Publishing and Printing Center. 1425

Borchert, Donald M, Encyclopedia of Philosophy, New York: Thompson Gale Corporation. 2006

51Husain, Heriyanto, 1435 H, p. 146 
Bunge, Mario,Matter and Mind, Montreal: Springer, 2010

Capra, Fritjof, The Web of Life, New York: An Anchor Book. 1996

Chittick, William C,The Heart of Islamic Philosophy: The Quest for Self-Knowledge in Teachings of Afdal al-Din Kashani, New York: Oxford University Press. 2001

Cole-Turner, Ronald,Transhumanism and Transcendence, Washington DC: George Town University Press, 2011

Coomaraswamy,Ananda K, The Essential Ananda K. Coomaraswamy, Bloomington: World Wisdom, 2004

------, Ananda K, What is Civilization?, United Kingdom: Lindisfarne Press, 1989

Groff, Peter. S,\& Leaman, Oliver,Islamic Philosophy A-Z, Edinburg: Edinburg University Press, 2007

Hanim Nur. (2014),'Pendidikan Akhlak: Komparasi Konsep Pendidikan Ibnu Miskawaih dan al-Ghazali', Ulumuna. 18(1).

Hastrodi, Tayafeeh, Aghakhan, Hashtroodi, "Concept of Chivalry (Futuwwah) According to Abd al-Razzaq Kashani: Analysis on His Tuhfah al-Ikhwan fi Khasais al-Fityan." PhD, Faculty of Islamic Thought University of Kuala Lumpur, Kuala Lumpur, 2015

Heriyanto, Husain, et.al,Hikmah Abadi Revolusi Imam Husain, Jakarta: Sadra Press, 1435

Huff, Toby E,The Rise of Early Modern Science, New York: Cambridge University Press, 2003

Irham, Iqbal,Muhammad, Menghidupkan Spiritualitas Islam: Kajian Terhadap Konsep Hudur Ibn al-Arabi, Jakarta: Semesta. 2016

Khorsidi, Faridi, Mona, (2013).'Comparing Mulla Sadra and Ibn Turka Viewpoints Regarding Angelic Inspiration', Basic. Appl. Sci. Res.3(2).

K. Vasiltov. (2004). 'Afdal al-Din Kashani and His Treaties: The Book of Everlasting',Orientalia, 10(4)

Labib, Muhsin, Pemikiran Filsafat Ayatullah M.T. Misbah Yazdi, Jakarta: Sadra Press. 2011.

Muthahhari, Murtadha, The Truth about al-Husayn's Revolt, trans. Najim alKhajifi, London: MIL London. 2002.

Al-Muqarram, Maqtal al-Husayn, Najaf: Adab. 1392. 
Nasr, Seyyed,Hossein, Knowledge and the Sacred, New York: State University of New York Press. 1989

-------,In Search of the Sacred, Colorado: Praeger. 2010

------, The History of Islamic Philosophy, London and New York: Routledge, 1996.

Rakhmat, Jalaluddin,Islam Aktual, Bandung: Mizan, 1991

Shirazi, Sadr al-Muta'alihin,Mazahir al-Ilahiyyah fi asrar al-Ulum al-Kamaliyyah, Tehran: Sadra Foundation of Islamic Philosophy. 1999 
116 | AJIS, Vol. 4 No. 2, Desember 2019 
Rahman, Amrullah, Supriatna,Building a Civilization Base ... | 117 